\title{
A Qualitative Analysis of Pakistan's External and Internal Debt
}

\section{Eatzaz Ahmad*}

\begin{abstract}
This paper discusses how poor debt management combined with the policies of donor agencies (particularly the IMF) have brought on the present domestic and foreign debt crises. The paper presents a qualitative account of the debt in Pakistan and then analyzes the debt data using various debt burden indicators. After the analysis of the economic and social costs of debt overhang in Pakistan, it is found that net foreign resource flows to the private and public sectors tended to crowd out private and public savings respectively and that public savings is crowded out by resource flows from the private sector to the public sector. Finally, the results of the paper find that the resource allocation between development and non-development expenditure did not depend on whether government expenditure was financed by revenues or government borrowing and that more resources are directed towards development activity when government expenditure is financed by foreign resource flows rather than domestic resource flows.
\end{abstract}

Keywords: Debt Burden, Savings, Development Expenditure, Pakistan.

JEL Classification: H63, H68.

\section{Introduction}

The current state of Pakistan's economy is characterized by low gross domestic product (GDP) growth, high inflation, lack of investment, economic mismanagement-especially in the energy sector-and continuing corruption. The general perception of other economic indicators is, by and large, also pessimistic. For example, it is often claimed that the burden of both foreign and domestic debt has increased above the levels that prevailed during the debt crisis of the 1990s. If we look at the relevant data, we find that, while the absolute volumes of

\footnotetext{
* Professor of Economics and Dean of the Faculty of Social Sciences, Quaid-i-Azam University, Islamabad.
} 
foreign and domestic debt have increased considerably in the last few years, it has yet to be determined terms whether Pakistan's capacity to sustain debt has worsened.

It appears as though, after a decade of calm, Pakistan is again on the brink of debt crises both on the foreign and domestic fronts. While the quantitative burden of external debt, as measured by the debt-to-GDP ratio has registered a significant increase from 58.57 percent in 2006/07 to 65.19 percent in 2010, the country's repayment capacity in terms of foreign exchange earnings and capital inflows does not present an alarming picture.

The debt crisis of the 1990s had several serious implications, the most important being the slowdown of economic activity as indicated by the GDP growth rate. ${ }^{1}$ This was accompanied by consistent budget and balance of payments deficits, which in turn narrowed the range of fiscal options available to economic managers. Since a large portion of government revenues was used to service debts, little room was left to undertake development activities in the public sector, with the result that public expenditure on education, health, and social welfare declined even in absolute terms. Poverty and the unequal distribution of income, which were almost forgotten, returned to occupy central stage in economic analyses.

If a debt crisis of the same magnitude as that of the 1990s should reoccur, the burden of its economic and social costs on citizens would be more severe this time. The already existing circular debt in the energy sector, which has choked economic activity flows, would add fuel to the fire. Additional complications would arise, especially for the poor and middle-income classes, due to deteriorating public infrastructure and high food prices. The balance of payments account, which appears in relatively good shape due to an unprecedented increase in foreign remittances, would be likely to deteriorate because of the expected increase in future debt servicing costs.

The unfolding economic scenario indicates the need to realign socioeconomic goals and make major changes to the policy framework. The social cost of these changes is expected to be high in the short run. The Ricardian equivalence argument does not apply for a number of

\footnotetext{
1 The annual compound growth rate of real GDP during the five-year period from 1995/96 to 1999/2000 was 2.76 percent, which was even lower than the growth rate achieved in any five-year period in Pakistan's history.
} 
reasons. First, a large percentage of households cannot afford to work out lifetime planning because they are too poor to generate savings. Second, capital markets are highly distorted both in terms of economic and administrative efficiency, and no proper pension schemes exist, except for government employees. Third, government economic policies are uncertain and often abruptly announced. The announcement of the annual budget has become almost futile because policies continue to change throughout the year. Many well-publicized policies often fall victim to public pressure and political considerations.

Although a preliminary analysis of the data shows indications of rising trends in debt ratios, the debt situation in Pakistan is not yet as poor as it was during the 1990s. Pakistan does not fall in the domain of an unsustainable debt scenario, and there appears to be some space in which to reverse the trend through deliberate efforts. However, moderately unfavorable external shocks such as a decrease in the flow of foreign remittances could bring debt into focus among professional economists and policymakers.

Since the trends in debt ratios are not consistent enough to forecast future trends with a reasonable degree of precision, this is postponed for future analysis when the picture is likely to become clearer. Instead, this study focuses on two tasks. First, it analyzes the composition of Pakistan's debt-related data, both foreign and domestic, in order to explore alternative ways of measuring the amount and burden of debt. This exercise provides useful information on the nature and size of the debt burden. The second part of the analysis attempts to trace the effects of foreign and domestic borrowing on domestic savings and on the allocation of the government budget between development and nondevelopment expenditures.

The paper is organized as follows. Section 2 presents a qualitative account of issues in debt management in Pakistan. Section 3 presents and analyzes debt data with the help of various debt burden indicators. The effects of debt and borrowing on savings and budget allocation are analyzed in Section 4. Finally, Section 5 concludes the study.

\section{Issues in Debt Management}

The responsibility for debt management in Pakistan lies mainly with the Ministry of Finance. Its subsections, namely the Economic Affairs Division (EAD) and Finance Division (FD), maintain relevant information on almost all aspects of debt management. The EAD 
monitors aid inflows, debt servicing, and the allocation of funds received in aid, grants, and borrowings. It also manages the technical assistance (training and infrastructure development) necessary to implement various aid programs. The FD is responsible for policymaking with regard to debt. Its Export Finance Wing plays a key role in designing medium- to long-term policies, keeping in view the inter-linkages between debt-related variables (e.g., borrowings and debt servicing) and the current and capital accounts of the balance of payments. Thus, the EAD performs the tasks of implementation, monitoring, and record keeping within the policy framework designed by the FD.

The State Bank of Pakistan (SBP) also maintains debt-related data, while the Central Directorate of National Savings records all information on domestic public debt raised by the government's National Savings Schemes (NSS). Debt management, planning, and policies at the Ministry of Finance are coordinated with the SBP in order to look into the financial side of the matter, and with the Planning Commission to seek economic advice.

Debt management in Pakistan is lacking in many respects, such as poor coordination across debt management agencies, lack of feasibility analysis and long-term planning, and a piecemeal approach to the problem. Donor agencies might also be blamed for imposing unrealistic conditionalities and for following their agenda without fully appreciating the ground realities.

As noted in the report by the Debt Reduction and Management Committee (Government of Pakistan, 2001), in practice debt management is segmented into many departments with poor coordination and information flows. The data management systems that are used are mostly outdated. Computer access across departments is not available. Although the use of computers to keep records has increased quite rapidly in recent years, the systems being used are upgraded with long time-lags because staff are not fully trained to keep pace with new innovations in information systems.

The situation at the EAD and SBP has improved in recent years as a result of generous technical assistance and training programs funded by the Asian Development Bank. The SBP has also implemented a wellplanned reform program and inducted fresh staff who are more familiar with and better oriented and able to adjust to advancements in finance and information technology. However, the use of modern information systems in debt management, accounting, and auditing practices in government departments, is by and large in its infancy. 
Economic problems in Pakistan, including the debt issue, are often addressed in crisis-like situations, and project feasibility and long-term planning are almost entirely confined to file work. As a result, solution strategies often seek quick results that, in most cases, are infeasible. Decision-making occurs mainly on whims and personal inclinations rather than objective analysis. Political motives and vested interests stand above socioeconomic considerations. Since political factors in Pakistan are volatile, long-term plans and feasibility reports, even when they exist, are given the least priority at the level of policymaking and implementation. The state of poor management in the energy, transport, and communication sectors-especially with reference to inter-organizational financial transactions, foreign direct investment, and privatization-is a glaring example of the state of affairs.

Another shortcoming of current debt management practices that is seldom highlighted in policymaking circles in Pakistan is the weak coordination between domestic and foreign debt. Again, the reason for such a piecemeal approach is the preoccupation with the most urgent task at hand. Confronted with the need to find ways and means to service foreign debt and minimize the associated default risk, debt management agencies tend to relegate domestic debt management to routine work. Even academic studies, with the exception of Ahmad (1996, 1997, 1999, 2000), and Ahmad and Ahmed (1998), tend to analyze foreign debt as an issue unrelated to domestic debt. Simulation exercises in Ahmad (1999) and Ahmad (2000) demonstrate how closely the two forms of debt are inter-linked. For example, a startling finding of this study is that attempts to retire external debt through privatization sales to foreign investors are most likely to end up retiring domestic debt, with little change in the size of foreign debt.

Statistics show that the burden of domestic debt is almost as large as that of foreign debt, both in terms of size and debt servicing costs. However, the foreign debt problem has turned into a crisis due to Pakistan's inability to accumulate the foreign exchange required for interest and principal payments, and the difficulty in rolling over the debt. Besides, common citizens, who have to pay a high price in terms of tough conditionalities imposed by the International Monetary Fund (IMF) for further loans, are far more informed about foreign debt than about domestic debt. Nevertheless, while Pakistan has never faced serious difficulty in rolling over domestic debt denominated in domestic currency, rising interest costs could potentially create a debt crisis on the domestic front as well. 
Along with poor debt management problems within Pakistan, donor agencies, particularly the IMF, have also had a share in aggravating the crisis. Despite all the apparent emphasis of the World Bank and IMF on poverty and the social sector, Pakistan experienced adverse trends on both accounts during the debt crisis of the 1990s. One reason for this was that the conditionalities attached to aid packages tended to neutralize the intended outcomes. Most IMF conditionalities, particularly on energy pricing, subsidies, and taxation, are based on hardcore neoclassical economics and lack a human touch. The primary focus of the conditionalities has been on resource generation through direct fiscal measures irrespective of their effects on the economy's capacity to sustain the debt burden. The most visible effect of the drive to reduce the budget deficit has been a sharp decline in public sector development expenditure.

Since the emergence of the debt crisis in the early 1990s, various initiatives have been taken to formulate debt management and reduction strategies. However, except for the attempt by the Debt Reduction and Management Committee (Government of Pakistan, 2001), the outcomes of the task forces have remained disappointing. For example, the wellpublicized National Debt Retirement Program launched in February 1997 could not produce any worthwhile impact although it resulted in an additional USD142.6 million worth of domestic debt in the form of US dollar bonds. The Committee's report brought into focus major weaknesses in debt management and measurement practices, and proposed some reforms to the system. The report recommended a number of qualitative and quantitative measures to achieve the above objectives. The solution strategy emphasized the following intermediate objectives.

- To improve the savings rate in the public sector.

- To improve total factor productivity in the public sector with better efficiency, better governance, and downsizing.

- To improve productivity in the private sector, especially in agriculture, manufacturing, and information technology.

- To improve the growth rate of real GDP.

- To privatize and downsize public assets and public services in education and health.

- To build economic confidence and promote economic stability. 
- To reschedule medium-term debt to avoid the immediate risk of debt default.

- To monitor the debt situation and implement a debt reduction strategy.

The report also recognized that the debt problem cannot be studied in isolation from the major components of the overall macroeconomic picture, and emphasized internal consistency, coherence, and sustainability of the policy framework. Most components of the solution strategy make good economic sense, but it is not clear how the debt problem should be integrated with other parts of the economic picture in quantitative terms and incorporated in the policy framework.

In response to the Committee's recommendations, the government agreed to set up a debt policy coordinating office in the Ministry of Finance to coordinate debt management issues across debt management agencies and to offer economic and financial advice. ${ }^{2}$ Although there were initial indications that some of the measures proposed in the report would be implemented, the proposal was later put in cold storage due to inter-departmental tussles.

To sum up, debt management in Pakistan is part of the larger problem of governance inefficiency. It was hoped that the democratically elected government would change the trend, but the old patterns of governance have reemerged. Institutional building is still a far cry from being realized. Governance inefficiency is addressed by creating duplicate institutions, while the existing institutions are left to disintegrate. Although the practice of hiring highly paid part-time consultants with little threat of accountability has been curtailed to some extent, it appears that we have not learnt our lesson as far as general management in the public sector is concerned.

Within the context of debt management, Pakistan is currently not under much pressure to show progress because of the windfall gains from 9/11. The success of debt management hinges on the ability of debt managers to acquire management autonomy from the bureaucratic mindset prevalent in government departments. Weak background analysis, the lack of political will, moral corruption, and bureaucratic inertia are the most common hurdles. The question of governance inefficiency is too well known and documented even in the reports of government task forces, but

\footnotetext{
${ }^{2}$ This information is based on a handout issued by the Ministry of Finance on 14 March 2001.
} 
there are always vested interests to disrupt the implementation of otherwise worthy proposals. The greatest fear raised in the report of the Debt Reduction and Management Committee (Government of Pakistan, 2001) was that its findings would never reach the implementation stage, and there are strong indications that confirm this fear.

It is also worth noting that donor agencies have time and again praised the policy framework of various governments, while the major source of disagreement has been on the implementation side. The point that is being missed is that slippage in targets occurs not because of shirking on the government's part but due to institutional weaknesses. The question of governance and institutional building needs to be brought into direct focus as intermediate targets with the ultimate aim of achieving the prescribed economic goals.

There is urgent need to relieve the government from such economic activities where there is no strong case of market failure. The financial sector, especially the banking, manufacturing, energy, and services sectors, need to be privatized on an urgent basis. Privatization is required not so much as to use the proceeds to retire debt as to improve economic efficiency and thereby to curtail the need for further borrowing. The debt problem needs to be linked to the question of sustainability rather than size. In other words, the focus needs to be placed on debt management rather than debt retirement.

\section{The Size and Burden of Debt}

\subsection{Data Availability}

Most data sources in Pakistan (particularly the Pakistan Economic Survey and Annual Report), which are also used in this study, have traditionally reported debt-related data meticulously for years until recently. ${ }^{3}$ The debt crisis of the 1990s and the subsequent need for data analysis by various task forces and committees forced data management agencies to think of more informative ways to report data. Although the information flow has improved considerably, additional data has been made available only for the last 16 years. The magnitude of debt reported by various data sources varies mainly due to differences in definition, while the debt burden estimates reported in various reports and

\footnotetext{
${ }^{3}$ The author would like to thank his MPhil Student, Misbah Aslam, for her invaluable assistance in data collection.
} 
academic studies differ additionally because of the different data sources being used. The main sources of disagreement are domestic debt in foreign currency (US\$ bonds and US\$ bearer certificates), foreign currency deposits in financial institutions by residents and nonresidents (mostly expatriates) and foreign currency deposits in the SBP by some Middle East countries.

Previously inaccessible information on military and private debts is now available. Previously unreported debt raised by certain debt instruments is now reported mainly because these instruments have gained importance in terms of the amount of debt raised and the associated risk due to their short-term nature.

\subsection{Aggregation Issues and Measurement of Debt and Liability}

Pakistan faces the twin problems of foreign and domestic debt, and most of its foreign debt is public or publicly guaranteed. However, alternative measures of debt can be derived depending on the nature of debt burden to be estimated. The measurement and classification of debt depends crucially on the ownership of debt or liabilities, debt instruments (e.g., loans, bonds, or deposits), the currency of denomination, the involvement of the public sector (e.g., public ownership or public guarantee), and maturity structure. Table 1 provides detailed information on various components of the country's debt and public liabilities for the last six years. 
Table 1: Foreign and Domestic Debt and Liabilities

\begin{tabular}{|c|c|c|c|c|c|c|c|c|c|c|c|c|c|}
\hline \multirow[t]{2}{*}{ Identification } & \multirow[t]{2}{*}{ Ownership } & \multirow{2}{*}{$\begin{array}{c}\text { Debt } \\
\text { Instruments }\end{array}$} & \multirow{2}{*}{$\begin{array}{l}\text { Denomination } \\
\text { Currency }\end{array}$} & \multirow[t]{2}{*}{ Nature } & \multirow{2}{*}{$\begin{array}{c}\text { Nature of } \\
\text { Liability }\end{array}$} & \multirow[t]{2}{*}{ Maturity } & \multicolumn{7}{|c|}{ Amount (USD billion) } \\
\hline & & & & & & & $\begin{array}{c}1989- \\
92\end{array}$ & $\begin{array}{c}1992- \\
95\end{array}$ & $\begin{array}{c}1995- \\
98\end{array}$ & $\begin{array}{c}1998- \\
2001\end{array}$ & $\begin{array}{c}2001- \\
04\end{array}$ & $\begin{array}{c}2004- \\
07\end{array}$ & $\begin{array}{c}2007 \\
-10\end{array}$ \\
\hline $\begin{array}{l}\text { Multilateral } \\
\text { and bilateral }\end{array}$ & $\begin{array}{l}\text { IFIs, foreign } \\
\text { countries }\end{array}$ & Loans & Foreign & PPG & Debt & LMT & 15.85 & 20.49 & 22.55 & 26.32 & 29.47 & 34.76 & 48.01 \\
\hline Euro bonds & Foreign FIs & Bonds & Foreign & PPG & Debt & LMT & & 0.15 & 0.56 & 0.63 & 0.65 & 1.94 & 2.12 \\
\hline Military loans & $\begin{array}{l}\text { Foreign } \\
\text { countries }\end{array}$ & Loans/credit & Foreign & PPG & Debt & LMT & & 2.13 & 1.29 & 0.99 & 0.43 & 0.13 & 0.14 \\
\hline $\begin{array}{l}\text { Multilateral } \\
\text { (IMF, IDB) }\end{array}$ & IFIs & Loans & Foreign & PPG & Debt & ST & 0.93 & 1.56 & 1.64 & 1.81 & 2.06 & 1.66 & 5.57 \\
\hline $\begin{array}{l}\text { Commercial } \\
\text { debt }\end{array}$ & Foreign FIs & Loans/credit & Foreign & PPG & Debt & ST & 0.56 & 0.89 & 1.13 & 1.12 & 0.25 & 0.15 & 0.15 \\
\hline Private debt & Foreign banks & Loans/credit & Foreign & Private & Debt & ST & 0.40 & 1.33 & 2.75 & 2.91 & 1.97 & 1.11 & 2.04 \\
\hline $\begin{array}{l}\text { Central bank } \\
\text { deposits }\end{array}$ & $\begin{array}{l}\text { Middle East } \\
\text { countries }\end{array}$ & $\begin{array}{l}\text { Savings } \\
\text { deposits }\end{array}$ & Foreign & PPG & Deposits & LMT & & 0.14 & 0.76 & 1.14 & 0.72 & 0.70 & 1.17 \\
\hline FCDs in FIs & Nonresident FIs & $\begin{array}{l}\text { Savings } \\
\text { deposits }\end{array}$ & Foreign & PPG & Deposits & ST & & 1.20 & 1.90 & 1.33 & 2.36 & 3.53 & 4.19 \\
\hline FCDs in FIs & $\begin{array}{l}\text { Nonresident } \\
\text { individuals }\end{array}$ & $\begin{array}{l}\text { Savings } \\
\text { deposits }\end{array}$ & Foreign & PPG & Deposits & $\mathrm{ST}$ & & 1.99 & 2.26 & 0.75 & 0.34 & 0.37 & 0.33 \\
\hline FCDs in FIs & $\begin{array}{l}\text { Resident } \\
\text { individuals }\end{array}$ & $\begin{array}{l}\text { Savings } \\
\text { deposits }\end{array}$ & Foreign & PPG & Deposits & ST & & 3.38 & 5.52 & 1.58 & 0.39 & 0.08 & 0.04 \\
\hline $\begin{array}{l}\text { Permanent } \\
\text { debt }\end{array}$ & $\begin{array}{l}\text { Resident } \\
\text { individuals }\end{array}$ & Bonds & Foreign & PPG & Debt & LMT & & 0.59 & 0.41 & 1.10 & 0.30 & 0.29 & 0.28 \\
\hline $\begin{array}{l}\text { Permanent } \\
\text { debt }\end{array}$ & $\begin{array}{l}\text { Domestic FIs, } \\
\text { citizens }\end{array}$ & Bonds & PKR & PPG & Debt & LMT & 6.37 & 9.21 & 7.58 & 6.35 & 8.28 & 8.91 & 9.42 \\
\hline $\begin{array}{l}\text { Unfunded } \\
\text { debt }\end{array}$ & Citizens & $\begin{array}{l}\text { Savings } \\
\text { certificates }\end{array}$ & PKR & PPG & Debt & LMT & 7.14 & 8.80 & 10.95 & 12.38 & 9.11 & 15.7 & 26.31 \\
\hline Floating debt & Domestic FIs & T- bills & PKR & PPG & Debt & ST & 6.21 & 6.48 & 8.89 & 12.48 & 14.78 & 14.98 & 16.67 \\
\hline
\end{tabular}


The table shows that the volume of the main component of debt, which has traditionally been the focus of analysis, has increased continuously in absolute dollar terms over the last 16 years. The other important debt component, short-term multilateral debt, has followed more or less the same trend. Furthermore, the rate of increase appears to have been quite sharp over the last three years (2007/08 to 2009/10), especially for short-term debt.

This picture is, however, incomplete unless we relate the debt volumes to the size of the economy. Since the rate of inflation in Pakistan has been much higher than the rate of depreciation of the Pakistan rupee against the US dollar, the rate of growth in nominal GDP has exceeded the rate of growth in debt in nominal Pakistan rupees. As a result, the debt-to-GDP ratio has registered a net decline. Further discussion on this is taken up later.

How an aggregate measure of debt or liabilities is formed depends on how we measure debt to foreigners or debt in foreign currency, debt in foreign currency or total liabilities in foreign currency, and public foreign debt or total (public plus private) foreign debt. However, care needs to be taken in lumping together all foreign currency liabilities on the public and private sectors on the basis that the central bank has to provide foreign currency to repay the latter in order to keep the banking system and foreign exchange market afloat. While liabilities in foreign currency may tighten the foreign exchange constraint, public debt constrains the overall financial position of the public sector; the two constraints do not always overlap.

Private liabilities in foreign currency do not constitute a net financial burden on the public sector, although pressure to repay on account of such liabilities may force the public sector to change the composition of its debt. At the time of repayment of such liabilities, especially when they are large, the central bank may deplete its foreign exchange reserves. Assuming that the government perseveres with its ongoing monetary and fiscal policies, the local currency thus collected can be converted into government securities to help retire public debt in local currency.

In accounting terms, the net liabilities/assets of the government or central bank remain unchanged. In economic terms, this amounts to retiring public debt in local currency by resorting to the central bank's foreign 
exchange reserves. ${ }^{4}$ In the past, this option was barely available in Pakistan while the central bank's reserves remained below USD2 billion. Although the reserves position has improved considerably over the last seven years, if the central bank chooses to raise foreign debt to restore its reserves position, the domestic debt in local currency will be replaced by foreign debt.

A third possibility is to let the private sector buy foreign currency from the open market. ${ }^{5}$ This would also leave the real burden of public debt unchanged, although the nominal burden might rise due to the depreciation of local currency and the associated inflation, assuming that the full Fisher effect is operative. Needless to say that in case depreciation does not fully translate into inflation, the real burden of foreign debt will rise, while if the interest rate on domestic debt does not adjust fully for inflation, the real burden of domestic debt will decline.

Apart from the considerations above, a meaningful aggregation of debt requires that the group of debtors and group of creditors do not overlap. Alternatively, while calculating the debt on a group of entities, the debt across entities within the group must be set equal to zero as it does not impose the net debt burden on the collective group. The same principle applies to nondebt liabilities. We could, for example, add public and private debt (or all liabilities) to foreigners to measure the debt (or overall liabilities) that a country-rather than its public sector-owes to foreign creditors. We cannot, however, add public and private debts (or all liabilities) in terms of foreign currency if the public debt (or liabilities) in foreign currencies includes debts (or liabilities) to residents because in the resulting aggregate domestic residents are counted both as debtors and creditors.

Table 1 identifies a number of important characteristics of debts and liabilities on the basis of which an aggregate measure of debt can be formed. Estimates of some of these aggregates for the last 16 years are shown in Table 2. As of June 2010, the total outstanding public debt in Pakistan was USD108.67 billion, a little more than half of which is denominated in foreign currency and a little more than half of which is foreign debt. This amount is close to 70 percent of the annual GDP, coming down from more than 95 percent of the GDP in 2000/01. Thus, foreign and domestic debt each constitute about a third of the annual GDP.

\footnotetext{
${ }^{4}$ In case the local currency sold by the private sector is absorbed in reducing the supply of highpowered money, the government's budget as well as the central bank's balance sheet will again show an unchanged net balance, and the public debt position will remain unchanged.

${ }^{5}$ This is equivalent to the central bank providing foreign currency to the private sector and restoring its balance through an open market purchase of foreign currency.
} 


\section{Table 2: Measures of Debt and Liability Aggregates (USD billion and Percentage of GDP)}

\begin{tabular}{lrrrrrr}
\hline Debt and Liability Aggregates & \multicolumn{5}{c}{ Amount (USD billion) } \\
\cline { 2 - 7 } & $\mathbf{1 9 9 2 -}$ & $\mathbf{1 9 9 5 -}$ & $\mathbf{1 9 9 8}$ & $\mathbf{2 0 0 1 -}$ & $\mathbf{2 0 0 4 -}$ & $\mathbf{2 0 0 7 -}$ \\
& \multicolumn{1}{c}{$\mathbf{9 5}$} & \multicolumn{1}{c}{$\mathbf{2 0 0 1}$} & \multicolumn{1}{c}{$\mathbf{0 4}$} & \multicolumn{1}{c}{$\mathbf{0 7}$} & \multicolumn{1}{c}{$\mathbf{1 0}$} \\
\hline Public debt & 50.30 & 55.00 & 63.18 & 65.33 & 78.52 & 108.67 \\
Long- and medium-term & 41.37 & 43.34 & 47.77 & 48.24 & 61.73 & 86.28 \\
Short-term & 8.93 & 11.66 & 15.41 & 17.09 & 16.79 & 22.39 \\
\hline Public debt in foreign currencies & 25.81 & 27.58 & 31.97 & 33.16 & 38.93 & 56.27 \\
Long- and medium-term & 23.36 & 24.81 & 29.04 & 30.85 & 37.12 & 50.55 \\
Short-term & 2.45 & 2.77 & 2.93 & 2.31 & 1.81 & 5.72 \\
Public debt in local currency & 24.49 & 27.42 & 31.21 & 32.17 & 39.59 & 52.40 \\
Long- and medium-term & 18.01 & 18.53 & 18.73 & 17.39 & 24.61 & 35.73 \\
Short-term & 6.48 & 8.89 & 12.48 & 14.78 & 14.98 & 16.67 \\
\hline Foreign public debt & 25.22 & 27.17 & 30.87 & 32.86 & 38.64 & 55.99 \\
Long- and medium-term & 22.77 & 24.40 & 27.94 & 30.55 & 36.83 & 50.27 \\
Short-term & 2.45 & 2.77 & 2.93 & 2.31 & 1.81 & 5.72 \\
Domestic public debt & 25.08 & 27.83 & 32.31 & 32.47 & 39.88 & 52.68 \\
Long- and medium-term & 18.60 & 18.94 & 19.83 & 17.69 & 24.90 & 36.01 \\
Short-term & 6.48 & 8.89 & 12.48 & 14.78 & 14.98 & 16.67 \\
\hline Foreign liabilities on Pakistan & 29.88 & 34.84 & 37.00 & 38.25 & 44.35 & 63.72 \\
Long- and medium-term & 22.91 & 25.16 & 29.08 & 31.27 & 37.53 & 51.44 \\
Short-term & 6.97 & 9.68 & 7.92 & 6.98 & 6.82 & 12.28 \\
Foreign public liabilities & 25.36 & 27.93 & 32.01 & 33.58 & 39.34 & 57.16 \\
Long- and medium-term & 22.91 & 25.16 & 29.08 & 31.27 & 37.53 & 51.44 \\
Short-term & 2.45 & 2.77 & 2.93 & 2.31 & 1.81 & 5.72 \\
Foreign private liabilities (short- & 4.52 & 6.91 & 4.99 & 4.67 & 5.01 & 6.56 \\
term) & & & & & & \\
\hline
\end{tabular}

GDP $=$ gross domestic product.

Sources: Government of Pakistan. (n.d.). Fifty years of Pakistan in statistics (Various issues). Islamabad: Federal Bureau of Statistics; Government of Pakistan. (n.d.). Pakistan economic survey (Various issues). Islamabad: Economic Adviser's Wing; Government of Pakistan. (n.d.). Statistical supplements (Various issues). Islamabad: Economic Adviser's Wing.

Looking at this from another angle, about four fifths of public debt is long- or medium-term, while the remaining fifth is short-term. Most of the short-term debt is domestic and is denominated in local currency. The short-term foreign debt is close to USD6 billion, which is about 5 percent of total debt and 10 percent of total foreign debt. 
If other liabilities in foreign currency-such as private debt and foreign currency deposits by foreigners at the central bank and domestic financial institutions-are added to Pakistan's foreign debt, the country's total foreign currency liabilities stand at about USD73 billion or about 47 percent of the annual GDP. The private sector's foreign liabilitiesmainly the foreign currency deposits of foreign financial institutions in domestic financial institutions and direct private debt-have remained more or less stable at USD6.5 billion.

\subsection{Trends in and Composition of Debt Burden}

The burden of foreign and domestic debt can be measured by expressing the volume of debt in terms of percentage of GDP. For this purpose, all magnitudes must be expressed in a common unit and indexed, if at all, similarly. The simplest approach is to measure debts as a percentage of GDP with both denominated in the local currency at current prices. Figure 1 shows the time profile of Pakistan's total, foreign, and domestic public debts as percentages of GDP.

Figure 1: Composition of Pakistan's Debt

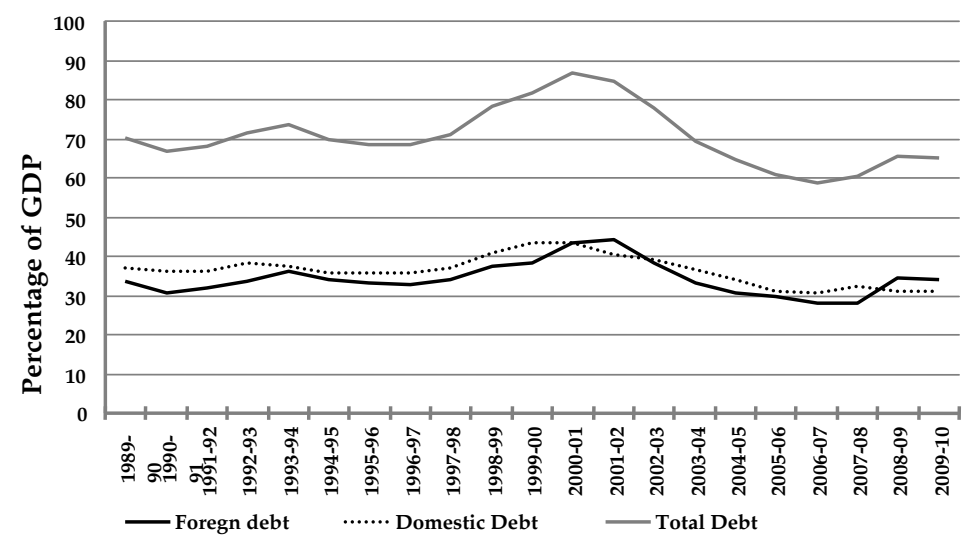

GDP = gross domestic product.

Sources: Government of Pakistan. (n.d.). Fifty years of Pakistan in statistics (Various issues). Islamabad: Federal Bureau of Statistics.

Government of Pakistan. (n.d.). Pakistan economic survey (Various issues). Islamabad: Economic Adviser's Wing.

Government of Pakistan. (n.d.). Statistical supplements (Various issues). Islamabad: Economic Adviser's Wing.

The figure shows that all three indicators of debt burden took a turn for the worse somewhere around 2007/08. However, the debt burden did not increase sharply and even flattened in the fiscal year 2009/10. This means that the rising trend in debt burden may not necessarily continue, and that there is a need to draw attention to other 
economic fundamentals and to study data more deeply before making any serious predictions about the debt scenario in the near future.

The sharp increase in Pakistan's total outstanding debt in 1998/99 was triggered mainly by the freeze on foreign currency deposits in May 1998, after the country had conducted a series of nuclear tests. The frozen accounts were later opened for withdrawal in local currency at the official exchange rate, while the open market rate had gone up by more than 20 percent in response to the unprecedented increase in demand for foreign currencies, especially the US dollar. Many depositors perceived the freeze as a lost opportunity to have made capital gains and for a while remained reluctant to withdraw their holdings in local currency. Nevertheless, the frozen accounts were gradually channeled into savings deposits in NSS or commercial banks. A small amount was also converted into US\$ bonds and bearer certificates.

The largest component of external debt is, by far, multilateral and bilateral long- and medium-term debt. Most of this debt is owed to international financial institutions and developed countries such as Japan and the US. The magnitudes of short-term public foreign debt and private foreign debt are relatively small and stable.

This trend was reversed in favor of Pakistan after 2001 when curbs were imposed on informal channels of international financial flows and Pakistan took a key position in the "war against terror." The continuously growing inflow of foreign remittances, which reached the USD1 billion mark per month, coupled with the rescheduling and writing off of its foreign debt eased the pressure on Pakistan's current account. This enabled the country to expand its foreign exchange reserves at the SBP and let the rupee appreciate in real terms by about 30 percent from $2001 / 02$ to $2009 / 10$.

Figure 2 shows the trends in and composition of the burden of Pakistan's total foreign exchange liabilities over the last several years. The figure reveals that, by far, the burden's largest component has been long/medium-term public debt. However, during the mid- to late 1990s, "other public foreign exchange liabilities" — consisting mostly of foreign currency deposits in the SBP and especially commercial banks-also contributed significantly to the overall burden. This component of the foreign debt burden has gradually decreased after a sharp decline in the late 1990s due to the freeze on foreign currency deposits. 


\section{Figure-2: Composition of Pakistan's Foreign Exchange Liabilities}

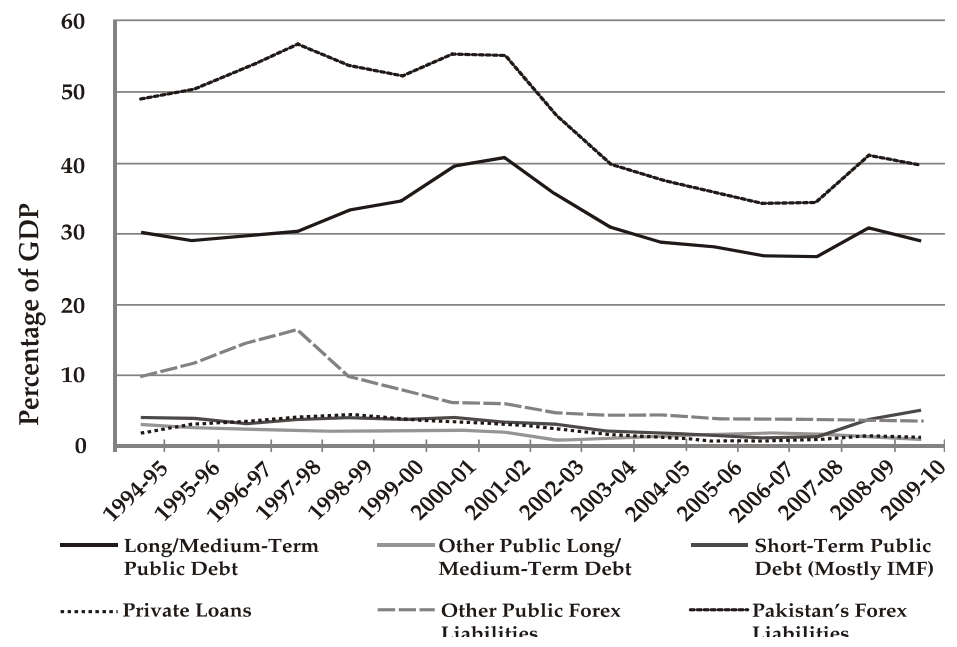

GDP $=$ gross domestic product, IMF = International Monetary Fund.

Sources: Government of Pakistan. (n.d.). Fifty years of Pakistan in statistics (Various issues). Islamabad: Federal Bureau of Statistics.

Government of Pakistan. (n.d.). Pakistan economic survey (Various issues). Islamabad: Economic Adviser's Wing.

Government of Pakistan. (n.d.). Statistical supplements (Various issues). Islamabad: Economic Adviser's Wing.

The most recent trend indicates that the burdens of long-/mediumterm debt and, hence, of the overall debt are mixed. After a sharp increase in 2008/09, the debt burden seems to have declined. On the other hand, the burden of short-term debt has continued to increase over the last three years mainly on account of borrowing from the IMF. The other components of the foreign debt burden appear small and less worrying.

Another way of classifying the burden of foreign exchange liabilities is to split it into public debt and nondebt foreign exchange liabilities. Figure 3 shows that the overall size of the burden is driven mainly by public debt, although the nondebt component had assumed an alarming position by the late 1990s.

Yet another way of classifying the burden of foreign exchange liabilities is to split it into long-/medium-term and short-term liabilities (Figure 4). Short-term foreign exchange liabilities consist of short-term public debt (mainly from the IMF), private loans from abroad, foreign currency deposits in commercial banks by residents and nonresidents, and foreign currency deposits in the SBP. The figure shows that the shortterm liabilities, which had assumed an alarming position toward the late 
1990s, have increased consistently over the last three years. The shortterm debt burden has risen to close to 10 percent of GDP, which seems to be a serious threat to Pakistan's debt sustainability.

\section{Figure-3: Pakistan's Foreign Public Debt and Other Foreign Exchange Liabilities}

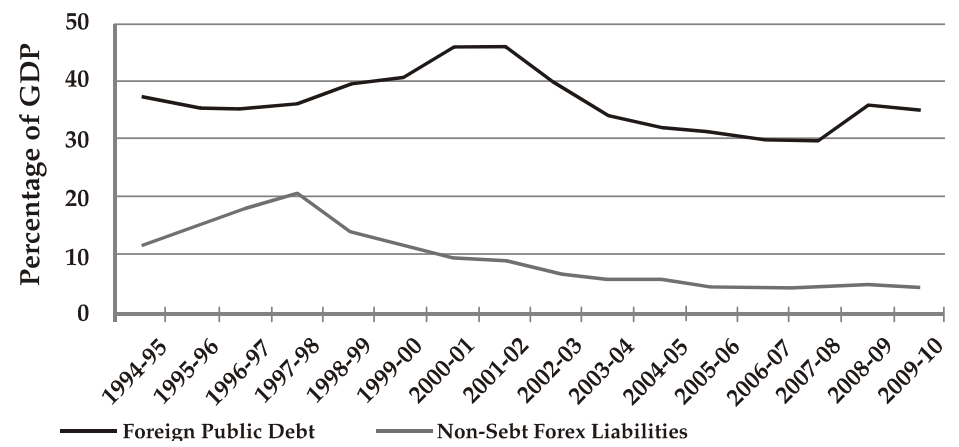

GDP = gross domestic product.

Sources: Government of Pakistan. (n.d.). Fifty years of Pakistan in statistics (Various issues). Islamabad: Federal Bureau of Statistics.

Government of Pakistan. (n.d.). Pakistan economic survey (Various issues). Islamabad: Economic Adviser's Wing.

Government of Pakistan. (n.d.). Statistical supplements (Various issues). Islamabad: Economic Adviser's Wing.

\section{Figure-4: Pakistan's Long and Short Term Foreign Exchange Liabilities}

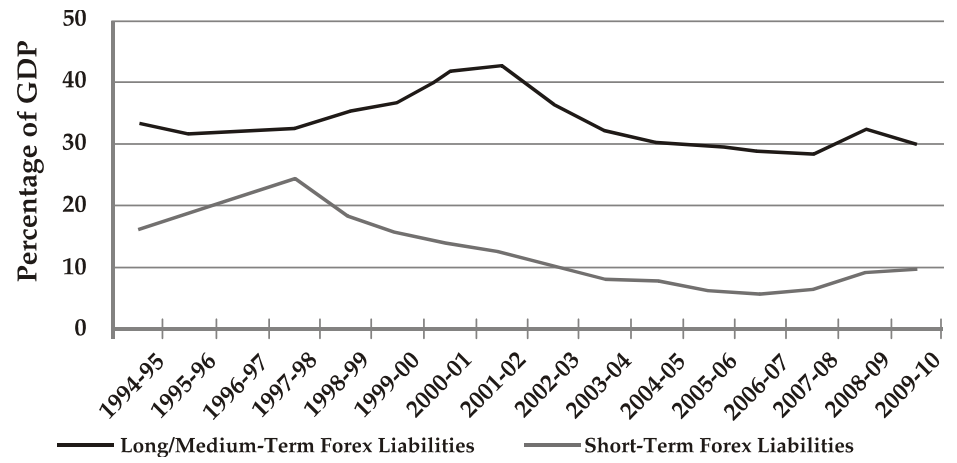

GDP = gross domestic product.

Sources: Government of Pakistan. (n.d.). Fifty years of Pakistan in statistics (Various issues). Islamabad: Federal Bureau of Statistics.

Government of Pakistan. (n.d.). Pakistan economic survey (Various issues). Islamabad: Economic Adviser's Wing.

Government of Pakistan. (n.d.). Statistical supplements (Various issues). Islamabad: Economic Adviser's Wing. 
Figure 5 shows that the burden of foreign debt comprises mainly public debt, while the size of private debt, which was somewhat visible in the late 1990s and early 2000s, has become relatively negligible (a little more than 1 percent of GDP).

\section{Figure-5: Pakistan's Public and Private Foreign Exchange Liabilities}

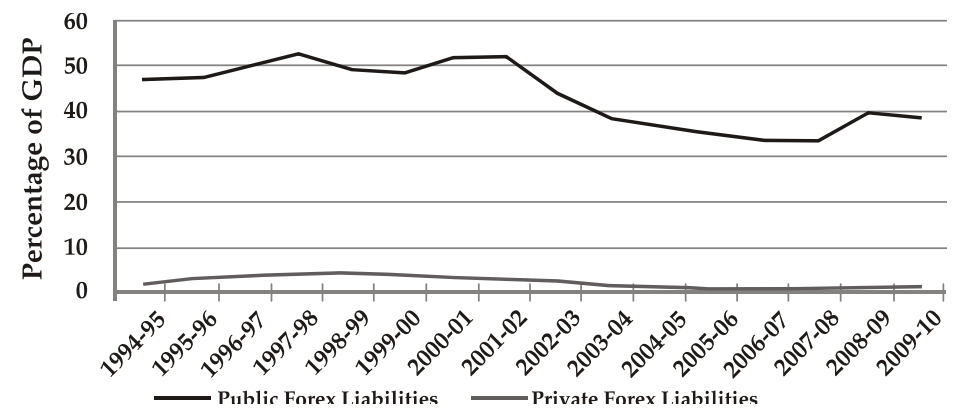

$\mathrm{GDP}=$ gross domestic product.

Sources: Government of Pakistan. (n.d.). Fifty years of Pakistan in statistics (Various issues). Islamabad: Federal Bureau of Statistics.

Government of Pakistan. (n.d.). Pakistan economic survey (Various issues). Islamabad: Economic Adviser's Wing.

Government of Pakistan. (n.d.). Statistical supplements (Various issues). Islamabad: Economic Adviser's Wing.

In order to highlight the importance of an increase in the burden of short-term foreign exchange liabilities, the time path of these liabilities (expressed as percentage of export earnings) is shown in Figure 6. The burden of short-term debt appears to be high not so much because of an increase in the absolute volume of these liabilities but because of the stagnation in export earnings over the last three years. The figure shows that short-term foreign exchange liabilities are close to 100 percent of export earnings. This percentage hovered around 200 during the late 1990s and came down to as low as 45.5 percent in 2006/07. Nevertheless, it is important to keep a close watch on this indicator in the near future. 


\section{Figure-6: Composition of Pakistan's Domestic Debt}

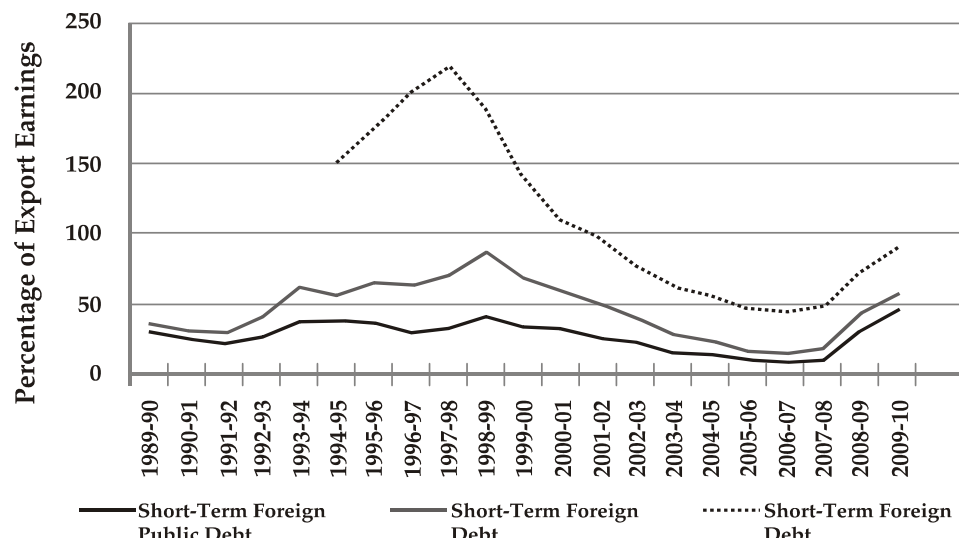

Sources: Government of Pakistan. (n.d.). Fifty years of Pakistan in statistics (Various issues). Islamabad: Federal Bureau of Statistics.

Government of Pakistan. (n.d.). Pakistan economic survey (Various issues). Islamabad: Economic Adviser's Wing.

Government of Pakistan. (n.d.). Statistical supplements (Various issues).

Islamabad: Economic Adviser's Wing.

Pakistan's domestic debt is classified as (i) permanent debt (medium and long-term), (ii) floating debt (short-term), or unfunded debt (nonbank or direct public borrowing). Permanent debt is resolved mostly by issuing long-term bonds with a maturity period of 3 to 10 years and prize bonds with no fixed maturity and a periodic distribution of interest to lottery winners.6 Floating debt is truly short-term debt, payment of which is raised by treasury bills. Finally, unfunded debt is based entirely on the NSS.

The Central Directorate of National Savings issues loan certificates directly to individual investors. The maturity period varies from 3 to 10 years with the exception of (unpopular) running savings accounts. Defense savings certificates, special savings certificates, and regular income certificates with maturity periods of 10, 3, and 5 years, respectively, are by far the most popular schemes. In this respect, unfunded debt is usually long-term.

Figure 7 shows that, during the past 40 years, the composition of domestic debt has changed quite substantially. Attractive real rates of return on the NSS with the added advantage of being tax-exempt resulted in a sharp rise in unfunded debt to bring it at par with floating debt till the early 2000s when the inflation rate remained low. Later, however, with the

\footnotetext{
${ }^{6}$ In the 1980s, the government also borrowed through bonds with a maturity period of up to 15 years.
} 
increase in the inflation rate and boom in property prices, NSS certificates became less attractive to investors to a large extent. Although the nominal volume of unfunded debt continued to show an increasing trend, the burden in terms of percentage of GDP registered a persistent decrease.

As a whole, the burden of domestic debt has declined considerably from its peak level of 43 percent at the turn of the century and stabilized at about 31 percent over the last five years. Thus, like foreign debt, the position of domestic debt is not as alarming as perceived or as it was during the 1990s.

\section{Figure-7: Composition of Pakistan's Domestic Debt}

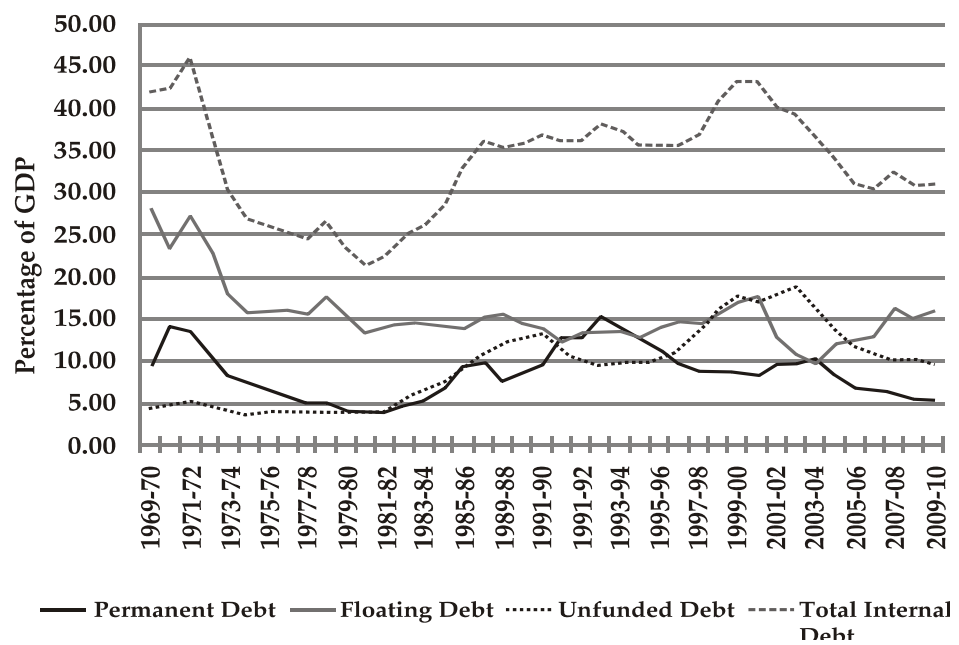

$\mathrm{GDP}=$ gross domestic product.

Sources: Government of Pakistan. (n.d.). Fifty years of Pakistan in statistics (Various issues). Islamabad: Federal Bureau of Statistics.

Government of Pakistan. (n.d.). Pakistan economic survey (Various issues). Islamabad: Economic Adviser's Wing.

Government of Pakistan. (n.d.). Statistical supplements (Various issues). Islamabad: Economic Adviser's Wing.

The financial pressure on the government to reduce the rates of return and withdraw tax exemptions on the NSS has eased due to high inflation. If the inflation rate continues to remain high, the government will have to raise interest rates on various savings instruments in the NSS. Presently, the government has no formal pension schemes for the public, and the NSS is considered the closest substitute offered by the public sector. Since these schemes operate on a fully-funded (rather than pay-asyou-go) basis, they are very much like private savings schemes, except that they offer better rates of return. 
Although no official documentation is available, it is generally perceived that elderly persons, mostly retired, hold a significant portion of funds invested in these schemes. Income on most popular schemes is tax-exempt, although 2.5 percent annual zakat levy on the principal value is deducted at the time of withdrawal. Since zakat is also deducted from all savings accounts in commercial banks and other financial institutions, it does not affect the relative attractiveness of the NSS vis-à-vis other available savings instruments.

The NSS gained popularity in the 1970s and has remained popular to date. This is explained partly by the increase in retirement savings due to improvements in life expectancy. The main reason, however, is that NSS certificates are considered safe assets as the rate of return has remained stable and there has never been any incidence of mismanagement or misappropriation of funds. It is encouraging to note that, despite operating a wide network of national saving centers, the Central Directorate of National Savings has been able to keep its operating costs low and shown a high degree of management efficiencya rare attribute in the public sector. As a result, the NSS has also proved to be the safest form of debt for the government.

Since these schemes have attributes similar to those of pension funds, there is ample room to expand their scope not only to help minimize the debt default risk, but to also provide the retired/elderly population with a safety net. At present, the Central Directorate of National Savings does not appear to have any effective marketing strategy to counter the aggressive marketing campaign run by commercial banks, and no innovative savings instruments have been introduced in a long time.

One could view this approach as pragmatic, because modernizing the schemes would add to their operating costs. Nevertheless, the scheme does not maximize its savings potential, and its scope could be expanded in many directions. For example, there is no scheme in which expatriate Pakistanis or even residents can accumulate retirement savings in foreign currency. This would certainly be an attractive way of restructuring at least a portion of foreign debt into retirement savings. Other savings instruments that could be introduced include a regular savings scheme for retirement income and a home ownership saving scheme. 


\section{Economic and Social Costs of Debt Overhang}

While estimating the explicit current cost of debt in terms of interest and principal payments is a straightforward process, it is not as easy to determine the real cost that an indebted country/government has to bear as a result of the resource reallocation necessary to service the outstanding debt. This paper focuses on the second aspect: to consider the consequences of debt servicing costs for resource allocation, in particular between consumption and savings and between development and nondevelopment activities within the public sector.

Several studies analyze the direct relationship between economic growth and external debt, while implicitly considering the channel of savings and, hence, investment (see, for example, Amoateng \& AmoakoAdu, 1996; Cohen, 1993; Elbadawi, Ndulu, \& Ndungu, 1997; Pattillo, Poirson, \& Ricci, 2002). Only a few studies (Clements, Bhattacharaya, \& Nguyen, 2003; Pattillo, Poirson, \& Ricci, 2004) take explicit account of the effects of debt on savings and/or investment. We now consider a relatively broader framework within which to analyze the effects of debt flows and debt servicing on the public and public savings, and the allocation of government expenditure toward development and nondevelopment activities.

Let us first consider savings. In the national income accounts, national savings are defined as domestic savings plus net factor income from abroad. This definition gives the impression that all net factor income from abroad is saved, while domestic savings appear to be underestimated. For economic analysis, one has to consider how national savings are generated rather than how they are accounted by statisticians. To understand the underlying savings behavior in Pakistan, we propose the following savings functions for the private and public sectors:

$$
\begin{aligned}
& S_{p}=a_{1}+a_{2}(Y-T)+a_{3} U+a_{4} F R P \\
& S_{g}=b_{1}+b_{2} T+b_{3} F R G+b_{4} D R G
\end{aligned}
$$

$S_{p}, S_{g}, Y, T, U, F R P, F R G$, and DRG denote private and public savings, GDP, tax plus nontax revenue/payments, private unrequited transfers from abroad, net foreign resource flows to the private and public sectors, and net resource flows from the private to public sector, respectively. Note that all the net resource flows to any particular sector are expressed 
in terms of its borrowings net of the interest payments on the corresponding outstanding debt (i.e., accumulated borrowings).

We expect private savings to be positively related to disposable income, while unrequited transfers and the marginal savings rate out of unrequited transfers is higher than that out of domestic disposable income. Furthermore, foreign resource flows to the private sector are expected to adversely affect private savings. Likewise, savings in the public sector are most likely to be directly related to government revenue and inversely related to foreign and domestic resource flows to the public sector.

Moving now to budget allocation in the public sector, there are many ways of classifying government expenditure. Based on the type of data available, we consider the allocation between current and development expenditures. The expenditure on interest payments on public debt-which is part of current expenditure-is given as it depends on the maturity structure of the debt, and the remaining balance is allocated to development and noninterest current expenditures. We denote noninterest total, current expenditure, development expenditure, government revenue, and net domestic and foreign resource flows to the public sector by $G, C E, D E, T, D R G$, and $F R G$, respectively. The government budget constraint can be written as

$$
G=C E+D E=T+D R G+F R G
$$

Although in an accounting sense current and development expenditures met through revenue and capital receipts are specified separately, this allocation is artificial because the actual allocation is generally affected by how the government budget is raised. For example, borrowing may force the government to cut its development expenditure from other sources, while on paper most of the development expenditure might be financed using borrowed funds. Furthermore, since external finance is expressed in terms of foreign currency, it can also affect the allocation depending on the foreign exchange requirements of current and development expenditures. In order to add behavioral content to the government budget, we postulate that the allocation of noninterest government expenditure between development and current expenditures depends on the composition of government resources and the burden of debt measured by the debt servicing (denoted by $D S$ ) to government revenue ratio. That is:

$$
D E / G=\alpha_{1} T / G+\beta_{1} D R G / G+\delta_{1} F R G / G+\phi_{1} D S / T+\varepsilon_{1}
$$




$$
C E / G=\alpha_{2} T / G+\beta_{2} D R G / G+\delta_{2} F R G / G+\phi_{2} D S / T+\varepsilon_{2}
$$

It follows from the budget constraint (3) that the regression parameters and random error terms satisfy the conditions

$$
\alpha_{1}+\alpha_{2}=\beta_{1}+\beta_{2}=\delta_{1}+\delta_{2}=1, \phi_{1}+\phi_{2}=0, \varepsilon_{1}+\varepsilon_{2}=0
$$

The budget constraint (3) also implies that the first three variables on the right-hand side of the above equations cannot move freely. For example, an increase in the $T / G$ ratio must be offset by appropriate changes in $D R G / G, F R G / G$, or both. There are various ways of imposing the government budget constraint on the behavioral equations depending on the type of changes in government resources that are to be analyzed. The relationships above can be written alternatively as

$$
\begin{aligned}
& D E / G=\alpha_{1}+\left(\beta_{1}-\alpha_{1}\right) D R G / G+\left(\delta_{1}-\alpha_{1}\right) F R G / G+\phi_{1} D S / T+\varepsilon_{1} \\
& C E / G=\alpha_{2}+\left(\beta_{2}-\alpha_{2}\right) D R G / G+\left(\delta_{2}-\alpha_{2}\right) F R G / G+\phi_{2} D S / T+\varepsilon_{2} \\
& D E / G=\left(\alpha_{1}-\beta_{1}\right) T / G+\beta_{1}+\left(\delta_{1}-\beta_{1}\right) F R G / G+\phi_{1} D S / T+\varepsilon_{1} \\
& C E / G=\left(\alpha_{2}-\beta_{2}\right) T / G+\beta_{2}+\left(\delta_{2}-\beta_{2}\right) F R G / G+\phi_{2} D S / T+\varepsilon_{2} \\
& D E / G=\left(\alpha_{1}-\delta_{1}\right) T / G+\left(\beta_{1}-\delta_{1}\right) D R G / G+\delta_{1}+\phi_{1} D S / T+\varepsilon_{1} \\
& C E / G=\left(\alpha_{2}-\delta_{2}\right) T / G+\left(\beta_{2}-\delta_{2}\right) D R G / G+\delta_{2}+\phi_{2} D S / T+\varepsilon_{2}
\end{aligned}
$$

It follows from the above that $\alpha_{1}$ and $\alpha_{2}$ measure the proportions of government noninterest expenditure allocated to development and noninterest current expenditures when the net domestic and foreign resource flows, and debt servicing cost are zero. This implies that the government budget is in balance, interest payments on debt for the current period are rescheduled, and debt volumes are constant.

The parameters $\beta_{1}$ and $\beta_{2}$ ( $\delta_{1}$ and $\delta_{2}$ ) measure the proportions of government noninterest expenditure allocated to development and noninterest current expenditures when the entire budget is financed by net domestic (foreign) resource flows; tax revenue, net foreign (domestic) resource flows, and debt servicing costs are zero. This is possible if all debt servicing (domestic as well as foreign) for the current period is rescheduled and net foreign (domestic) borrowing is zero. 
The scenarios above are unrealistic in practice. A better interpretation is based on the differences in parameters $\alpha_{i}-\beta_{i}, \alpha_{i}-\delta_{i}, \beta_{i}$ $\delta_{i}$, etc. Thus, for example, $\alpha_{1}-\beta_{1}$ and $\alpha_{2}-\beta_{2}$ measure the sensitivity of budget allocation between development and noninterest current expenditures to the replacement of net domestic resource flows by equal government revenues. The other combinations listed in (4b) to (5c) can be interpreted likewise.

Table 3 presents estimates of the savings functions. Before discussing these results, it is important to note that the data on savings in Pakistan is not very reliable, and that figures in different sources vary substantially. ${ }^{7}$ Thus, one cannot be overly confident of the level of statistical confidence shown by the computed t-statistics, and the results might be better seen in qualitative rather than quantitative terms. Nevertheless, some interesting results follow from the estimates.

If the marginal propensity of public consumption from tax revenue is taken into account, the net impact of each additional rupee of tax on national savings is calculated to be 0.4 of a rupee. Thus, the assumption that Pakistan can reduce its resource deficiency by imposing additional taxes is subject to debate.

\footnotetext{
${ }^{7}$ This is not true for all types of data. In particular, debt statistics are quite reliable although the definition of "debt" is debatable. This is because record keeping at the EAD (which maintains all data on debt) and at the SBP is much better than at other government departments.
} 
Table 3: Estimates of Savings Functions

\begin{tabular}{lcc}
\hline & Private Savings & Public Savings \\
\hline Intercept & -33.105 & -10.305 \\
& $\left(-2.20^{*}\right)$ & -0.89 \\
Gross domestic product & 0.171 & \\
& $\left(10.48^{*}\right)$ & \\
Tax plus nontax revenue/payment & -0.171 & 0.57 \\
& $\left(-10.48^{*}\right)$ & $\left(10.51^{*}\right)$ \\
Private unrequited transfers & 0.482 & \\
& $\left(1.70^{* *}\right)$ & \\
Net foreign resource flows to private sector & -0.445 & \\
& $\left(-2.73^{*}\right)$ & \\
Net foreign resource flows to public sector & & -0.636 \\
& & $(-1.54)$ \\
Net resource flows from private to public & & -0.815 \\
sector & & $\left(-5.03^{*}\right)$ \\
R2 & 0.883 & 0.929 \\
DW statistics & 2.43 & 2.10 \\
Mean & 117.24 & 70.94 \\
\hline
\end{tabular}

The t-statistics significant at 5 and 10 percent are marked ${ }^{*}$ and ${ }^{* *}$, respectively.

The results also support the hypothesis that the marginal private savings rate out of unrequited transfers from abroad is higher than that out of domestic disposable income. This result is at least plausible because studies show that investment activity is much higher among households that receive remittances as compared to the average household. One reason for this trend is that, in many cases, migrants have a lifetime opportunity to earn a large income for a contract period overseas or that they do not want to remain separated from their families back home beyond a certain period. Therefore, they have to count their temporarily large incomes in a lifecycle context.

The net foreign resource flows to the private and public sectors are found to crowd out private and public savings, respectively. Furthermore, public savings are also crowded out by resource flows from the private to public sector. This indicates that public domestic or foreign borrowings as well as private borrowing adversely affect domestic saving efforts and the loss in savings is quite large. 
Parameter estimates for the budget allocation model (Equations 4 and 5) are presented in Table 4.8 As can be seen, the overall fit of the model is good and there is no strong incidence of autocorrelation. The results show that if all the government expenditure is met through government revenues and there is no burden of debt servicing, the development and current expenditure components of the government budget will be 42.3 and 57.7 percent, respectively.

Comparing these proportions with the actual sample means (31.6 and 68.4 percent, respectively), one can see that the expenditure allocated to development activities would be higher under the hypothetical scenario, and that the difference is statistically significant.

The $t$-statistic for the difference between the projected proportion of development or current expenditure and the corresponding mean proportion in the sample is found to be 2.36, which is significant at 5 percent. In the case where all government expenditure is met through domestic or, in particular, foreign resource flows and debt servicing is zero, the expenditure allocated to development activities will be even higher.

In all these cases, debt servicing is assumed to be zero, so it follows that the burden of debt servicing on development expenditure will be disproportionately higher. This pattern is evident from the sign and significance of the coefficient on debt servicing, which indicates that, for example, an increase in debt servicing by 10 percent of government revenue would shrink the share of development expenditure by 3.07 percent of total government expenditure.

\footnotetext{
${ }^{8}$ The parameter estimates of the budget allocation model can be obtained using any one of the three specifications (4a and 5a, $4 \mathrm{~b}$ and $5 \mathrm{~b}$, or $4 \mathrm{c}$ and $5 \mathrm{c}$ ) to yield identical results. Furthermore, parametric restrictions imposed by the government budget constraint imply that the parameters of any one equation can be derived from the estimated parameters of the other equations within each of the budget allocation models.
} 
Table 4: Estimate of Model of Allocation between Development and Noninterest Current Expenditures

\begin{tabular}{lcc}
\hline Variable (Parameter) & $\begin{array}{c}\text { Development } \\
\text { Expenditure }\end{array}$ & $\begin{array}{c}\text { Current } \\
\text { Expenditure }\end{array}$ \\
\hline Government revenue to government & 0.423 & 0.577 \\
expenditure ratio $\left(\alpha_{i}\right)$ & $\left(9.31^{*}\right)$ & $\left(12.69^{*}\right)$ \\
Net domestic resource flow to government & 0.479 & 0.521 \\
expenditure ratio $\left(\beta_{i}\right)$ & $\left(6.81^{*}\right)$ & $\left(7.40^{*}\right)$ \\
Net foreign resource flow to government & 0.789 & 0.211 \\
expenditure ratio $\left(\delta_{i}\right)$ & $\left(4.60^{*}\right)$ & $(-1.23)$ \\
Debt servicing to government revenue ratio $\left(\phi_{i}\right)$ & -0.307 & 0.307 \\
& $\left(-3.83^{*}\right)$ & $\left(3.83^{*}\right)$ \\
$\beta_{i}-\alpha_{i}$ & 0.056 & -0.056 \\
& $(0.51)$ & $\left(-0.51^{*}\right)$ \\
$\delta_{i}-\alpha_{i}$ & 0.366 & -0.366 \\
& $\left(1.85^{* *}\right)$ & $\left(-1.85^{* *}\right)$ \\
$\alpha_{i}-\beta_{i}$ & -0.056 & 0.056 \\
$\delta_{i}-\beta_{i}$ & $(-0.51)$ & $(0.51)$ \\
& 0.310 & -0.310 \\
$\alpha_{i}-\delta_{i}$ & $\left(2.02^{* *}\right)$ & $\left(-2.02^{* *}\right)$ \\
$\beta_{i}-\delta_{i}$ & -0.366 & 0.366 \\
R2 & $\left(-1.85^{* *}\right)$ & $\left(1.85^{* *}\right)$ \\
DW statistic & -0.310 & 0.310 \\
Mean dependent variable & $\left(-2.02^{* *}\right)$ & $\left(2.02^{* *}\right)$ \\
\hline
\end{tabular}

The t-statistics significant at 5 and 10 percent are marked ${ }^{*}$ and ${ }^{* *}$, respectively.

Turning to the more interesting part of analysis, the results indicate that replacing domestic or foreign resource flows with government revenue would reduce the government expenditure allocated to development activities. According to the parameter estimates if, for example, domestic or foreign resource flows equal to 10 percent of noninterest government expenditure are replaced with additional government revenue, development expenditure will decrease by 0.56 percent and 3.66 percent of noninterest government expenditure, respectively, with the latter effect significant at 10 percent. The results also show that replacing foreign with domestic resource flows by 10 percent of noninterest government expenditure will significantly squeeze development expenditure by 3.1 percent of noninterest government expenditure. 
Three basic results emerge from this statistical analysis: First, resource allocation between development and nondevelopment activities does not depend crucially on whether government expenditure is financed by revenues or domestic borrowing. Second, resource allocation leans more toward development activity when government expenditure is financed by foreign resource flows rather than by revenue or domestic resource flows. Third, the burden of debt servicing falls disproportionately on development activity.

Several implications follow from the above conclusion. The most obvious is that the data does not support the perception that Pakistan has reached its current state because most of its borrowing is used for consumption rather than development-and that aid funds are misused. Although development activity in Pakistan has fallen sharply, particularly during the 1990s, this has been the result of twin factors: shrinking foreign resource flows and rising debt servicing costs. There are many instances of the misappropriation of public resources, and unfortunately such instances tend to overshadow the positive side.

Another conclusion that follows from our statistical results is that the government in Pakistan has not felt sufficiently pressured to use domestically borrowed funds for development activities despite the fact that the volume of domestic debt is almost equal to the volume of foreign debt. A plausible explanation is that domestic borrowing in Pakistan is mostly from individual lenders or financial institutions that lend voluntarily in return for high interest rates and are not organized enough to impose preconditions for lending. On the other hand, most foreign borrowing is directly or indirectly linked to international institutions whose motive for lending is not to earn interest. In order to justify further lending, Pakistan has to satisfy its lenders that the borrowed funds are used productively.

Another conclusion is that noninterest current expenditure in Pakistan is mostly inelastic, with about 45 percent allocated to defense and 25 percent to administration. While there is a general reluctance to reduce the share of defense expenditure unless the armed forces voluntarily agree to a cut, the administrative expenditure is by nature inelastic, keeping in view the rising population. The salaries of government employees and expenditure on agencies that are responsible for law and order cannot be significantly reduced unless large-scale restructuring is carried out. Government employees' salaries were recently adjusted for inflation, and the law and order situation demands even further spending. Other current expenditures on subsidies and 
social, economic, and community services are already meager. Thus, the government have little option but to cut development expenditure to make room for debt servicing. However, the options are shrinking rapidly as the share of development expenditure has already been drastically reduced over the last several years.

\section{Concluding Remarks}

This paper has attempted to understand the nature and size of the debt problem facing Pakistan by considering some of its important dimensions-historical and political economy perspectives, debt measurement issues, debt burden indicators, and the implications of debt for resource allocation. Several interesting conclusions that can be drawn from the study are summarized below.

Definitions of debt measures as reported in various data sources tend to vary. The sources of disagreement include domestic debt in foreign currency (US\$ bonds and US\$ bearer certificates), foreign currency deposits in financial institutions by residents and nonresidents (mostly expatriates), and foreign currency deposits in the SBP by some Middle East countries. Thus, debt is measured depending on the nature of debt burden to be estimated. The measurement and classification of debt depends crucially on the ownership of debt or liabilities, debt instruments (e.g., loans, bonds, or deposits), the currency of denomination, the involvement of the public sector (e.g., public ownership or public guarantee), and the maturity structure.

In any case, Pakistan's long-term and short-term debts have been continuously increasing in absolute dollar terms over the last 16 years, and the rate of increase has accelerated in the last three years (2007/08 to 2009/10). Since the inflation rate has been much higher than the rate of depreciation of the rupee against the US dollar, the rate of growth in nominal GDP has exceeded the rate of growth in debt in nominal rupees, with the result that the debt-to-GDP ratio has registered a net decline.

Pakistan's current debt burden constitutes about 70 percent of GDP, having come down from more than 95 percent of the GDP in 2000/01. Foreign and domestic debts each comprise about one third of the annual GDP. If other liabilities in foreign currency-such as private debt and foreign currency deposits by foreigners at the central bank and domestic financial institutions-are added to Pakistan's foreign debt, the country's total foreign currency liabilities stand at about 47 percent of the 
annual GDP. From another perspective, about four fifths of public debt is long or medium-term, while the remaining one fifth is short-term. Most of the short-term debt is domestic and is denominated in local currency.

By far the largest component of external debt is multilateral and bilateral long and medium-term debt, most of which is owed to international financial institutions and developed countries such as Japan and the US. The burden of short-term liabilities expressed as a percentage of export earnings (Figure 6) appears to be more alarming: the burden is high not so much due to an increase in the absolute volume of these liabilities as because export earnings have stagnated during the last three years. Short-term foreign exchange liabilities are close to 100 percent of export earnings. This percentage hovered around 200 during the late 1990s and came down to as low as 45.5 percent in 2006/07. Keeping a close watch on the indicator in the near future will be important.

Pakistan's domestic debt is classified as permanent debt (mediumand long-term bonds and short-term prize bonds), floating debt (shortterm treasury bills), or unfunded debt (mostly medium- and long-term direct public borrowing through the NSS). Although the nominal volume of unfunded debt continues to show an increasing trend, the burden in terms of percentage of GDP has registered a persistent decrease. As a whole, the burden of domestic debt has declined considerably from its peak level of 43 percent at the turn of the century and stabilized at around 31 percent over the last five years. Thus, like foreign debt, the position of domestic debt is not as poor as perceived or as it was during the 1990s.

In the last 40 years, the composition of domestic debt has changed quite substantially. Attractive real rates of return on the NSS (with the added advantage of tax exemption) caused a sharp rise in unfunded debt and brought it at par with floating debt till the early 2000s when the inflation rate was low. Later, however, the increase in the inflation rate and boom in property prices meant that the NSS became a far less attractive option. Since these schemes have many of the attributes of pension funds, there is ample room to expand their scope, not only to minimize the debt default risk, but also to provide the retired/elderly population with a safety net.

At present, the Central Directorate of National Savings does not appear to have any effective marketing strategy to counter the aggressive marketing campaign run by commercial banks, and it has been a long time since any innovative savings instruments were introduced. This approach 
is a pragmatic one because modernizing the schemes would add to their operating costs. Nevertheless, they do not maximize their savings potential and there are many directions in which the scope of such schemes could be extended. For example, there is no scheme under which expatriate Pakistanis or even residents can accumulate retirement savings in foreign currency. This would certainly be an attractive way to restructure at least a portion of foreign debt into retirement savings. Other savings instruments that could be introduced include a regular savings scheme for retirement incomes and a home ownership savings scheme.

In terms of the impact of debt-related flows on savings, we have found that the net foreign resource flows to the private and public sectors tend to crowd out private and public savings, respectively. The latter is also crowded out by resource flows from the private to public sector, implying that public domestic or foreign borrowing as well as private borrowing adversely affects domestic saving efforts, and that there is a substantial loss in savings.

We have drawn three important conclusions concerning the implications of foreign and domestic debt for the government's budget allocation decisions: (i) resource allocation between development and nondevelopment activities does not depend crucially on whether government expenditure is financed by revenues or domestic borrowing, (ii) resource allocation leans more toward development activities when government expenditure is financed by foreign resource flows rather than by revenue or domestic resource flows, and (iii) the burden of debt servicing falls disproportionately on development activity.

The perception that most of the borrowing is used for consumption rather than development activities-and that therefore aid funds are misused-does not appear to hold true for Pakistan. Although the level of development activity in Pakistan has fallen sharply, particularly during the 1990s, this has been the result of shrinking foreign resource flows and rising debt servicing costs. There are many instances of the misappropriation of public resources, and unfortunately such instances appear to overshadow the positive side.

That said, successive governments in Pakistan do not seem to have used domestically borrowed funds for productive purposes even though the volume of domestic debt is almost equal to the volume of foreign debt. This could be because domestic borrowing in Pakistan is mostly from individual lenders or financial institutions that lend 
voluntarily in return for high interest rates and are not organized enough to impose preconditions for lending, as happens in the case of institutional foreign lending. A possible way out would be to impose constitutional limits on the proportion of borrowed funds that can be used for nondevelopment activities. 


\section{References}

Ahmad, E. (1996). Capital flows and national debt. Pakistan Development Review, 35(4), 943-960.

Ahmad, E. (1997). Dynamics of foreign and domestic borrowing and debt. Journal of Economic Cooperation among Islamic Countries, 18(3), 71113.

Ahmad, E. (1999). Retiring public debt through privatization. Pakistan Journal of Applied Economics, 15(1-2).

Ahmad, E. (2000). Getting out of the debt trap: Simulating debt retirement strategies for Pakistan (Occasional Paper No. 12). Islamabad, Pakistan: LEAD.

Ahmad, E., \& Ahmed, A. (1998). A simulation analysis of debt problem in Pakistan. Pakistan Development Review, 37(4), 355-376.

Amoateng, K. A., \& Amoako-Adu, B. (1996). Economic growth, exports and external debt causality: The case of African countries. Applied Economics, 28, 21-27.

Burney, N. (1988). Determinants of debt problem in Pakistan and its debt servicing capacity. Pakistan Development Review, 27(4), 805-816.

Chaudhary, M. A. (1988). International debt and foreign dependency: Policy options for Pakistan. Pakistan Development Review, 27(4), 829-836.

Clements, B., Bhattacharaya, R., \& Nguyen, T. Q. (2003). External Debt, Public Investment, and Growth in Low-Income Countries (Working Paper No. 03/249). Washington, DC: International Monetary Fund.

Cohen, D. (1988). The management of the developing countries' debt: Guidelines and applications to Brazil. World Bank Economic Review, 2(1), 77-103.

Cohen, D. (1993). Low investment and large LDC debt in the 1980s. American Economic Review, 83(3), 437-449. 
Crouch, R. L. (1973). Economic development, foreign aid, and neoclassical growth. Journal of Development Studies, 9, 353-364.

Elbadawi, A. I., Ndulu, J. B., \& Ndungu, N. (1997, December). Debt overhang and economic growth in Sub-Saharan Africa. Paper presented at the International Monetary Fund/World Bank conference on External Debt for Low-Income Countries, Washington, DC.

Government of Pakistan. (2001). A debt burden reduction and management strategy. Islamabad, Pakistan: Ministry of Finance.

Government of Pakistan. (n.d.). Fifty years of Pakistan in statistics (Various issues). Islamabad: Federal Bureau of Statistics.

Government of Pakistan. (n.d.). Pakistan economic survey (Various issues). Islamabad: Economic Adviser's Wing.

Government of Pakistan. (n.d.). Statistical supplements (Various issues). Islamabad: Economic Adviser's Wing.

Khan, S. R. (1997). Has aid helped in Pakistan? Pakistan Development Review, 36(4), 853-883.

Pattillo, C., Poirson, H., \& Ricci, L. (2002). External debt and growth (Working Paper No. 02/69). Washington, DC: International Monetary Fund.

Pattillo, C., Poirson, H., \& Ricci, L. (2004). What are the channels through which external debt affects growth? (Working Paper No. 04/15). Washington, DC: International Monetary Fund.

State Bank of Pakistan. (n.d.). Annual report (Various issues). Karachi. 